UDC502.131.1: 677.021.15

JEL Classification: L65; Q55

DOI: https://doi.org/10.32317/2221-1055.201911079

L.H. MELNYK, doctor of economic sciences, professor

O.V. KUBATKO, doctor of economic sciences,

associate professor (docent)

V.S. PIVEN

P.V. KUCHERENKO

V.M. IHNATCHENKO, postgraduate student*

\title{
Bioplastics production for circular economy and sustainable development promotion
}

The purpose of the article is to investigate advantages and drawbacks of using bioplastic materials, to explore their environmental, economic and social effects in comparison with the conventional plastics ones.

Research methods. In the research process was used the comparative analysis method for investigation of advantages and drawbacks of using bioplastic materials.

Research results. The paper states that bioplastics has a special environmental advantages over oil-based plastics to minimize reliance on limited fossil fuels and to shorten emissions of greenhouse gases. In addition, it is stated that bioplastics promotes to energy security of domestic economy through lower energy resources consumption and lower reliance on petroleum. The short run economic advantages of bioplastics are not overweighing by oil-based plastics. However, long-run perspective of bioplastics production is vivid due to declining a level of waste pollution and increased compostability of biodegradable bioplastics. According to the results, bioplastics seems to have many advantages in comparison with conventional plastics, including decreased carbon footprint, lower consumption of energy, numerous end-of-life choices, reduction of waste, increased compostability of biodegradable bioplastics, decreasing a level of greenhouse gas emissions, work creation, disposal of agricultural film, better technical characteristics. These advantages encourage the bioplastic market to grow. However, unsustainable land use, the price of oil and its sales amounts, low level of consumers' engagement, legislation problems are significant barriers for increasing the bioplastic usage, which need to be taken into account.

Elements of scientific novelty. It is proposed theoretical concept of bioplastics production, which in contrast to existing one, takes into consideration the pros and cons of bioplastics production on all stages of the product promotion for stimulating Circular Economy and Sustainable Development fostering.

Practical significance. The practical significance lies in the fact that all proposed approaches could be used for the development of real life business plans and developing strategies of local development. Refs.: 14.

Keywords: bioplastics; advantages of bioplastics; disadvantages of bioplastics; sustainable economy; green economy.

Melnyk Leonid Hryhorovych - doctor of economic sciences, professor, head of the department of economics, entrepreneurship and business administration, Sumy State University, director of Research Institute for Development Economics (IDE) at Sumy State University, Ministry of Education and Science of Ukraine, National Academy of Science of Ukraine (2, Rymskoho-Korsakova st., Sumy)

E-mail: melnyk@econ.fem.sumdu.edu.ua

ORCID iD https://orcid.org/0000-0001-7824-0678

Kubatko Oleksandr Vasylovych - doctor of economic sciences, associate professor (docent), associate professor (docent) of the department of economics, entrepreneurship and business administration, Sumy State University (2, Rymskoho-Korsakova st., Sumy)

E-mail: okubatko@ukr.net

Piven Vladyslav Serhiiovych - student of Oleg Balatskyi Academic and Research Institute of Finance, Economics and Management, Sumy State University (2, Rymskoho-Korsakova st., Sumy)

E-mail: a.piven@ms.sumdu.edu.ua

Kucherenko Polina Valeriivna - student of Oleg Balatskyi Academic and Research Institute of Finance, Economics and Management, Sumy State University (2, Rymskoho-Korsakova st., Sumy)

E-mail: Poulina.Kucherenko@gmail.com

Ihnatchenko Vitalii Mykhailovych - postgraduate student of the department of economics, entrepreneurship and business administration, Sumy State University (2, Rymskoho-Korsakova st., Sumy)

E-mail: Ignatchenko91@e-mail.ua

\footnotetext{
* Scientific supervisor - O.V. Kubatko, doctor of economic sciences, associate professor (docent).
}

(C) L.H. Melnyk, O.V. Kubatko, V.S. Piven,

P.V. Kucherenko, V.M. Ihnatchenko, 2019 
Scientific problem. Figures for the world plastic production from 1960 to 2018 show that the average annual growth rate was $8.9 \%$. World production of plastics amounted to 336 million tons in 2018 compared to 323 million tons in 2017 (an increase of 13 million tons in one year), according to data provided by the United Nations. Because plastic materials are commonly used in a variety of applications, problems connected with economics and environment have arisen. As a result, environmentally friendly materials such as bioplastics have been created. Bioplastic use is growing worldwide, with key drivers for increasing usage, including: an ability to provide opportunities to minimize dependence on various fossil fuels; decreasing the level of greenhouse gas emissions; improved technological and quality characteristics; regulatory incentives of many countries, such as tax benefits and a range of end-of-life options, including composting [9]. Despite many substantial advantages of bioplastics, there is a range of disadvantages, which need to be considered. Therefore, it is important to analyze main advantages and disadvantages of using bioplastic materials. Such research will be helpful in the context of identifying the basic barriers and opportunities of using bioplastics throughout the world and providing recommendations to minimize negative effects from their application.

Analysis of recent research and publications. Many scientists have studied the role of bioplastics in sustainable and green economy as a substitute to conventional plastics, in particular, such as E. Stevens, J. Ying, L. Shen, E. Worrell, M. Patel, D. Sawyer, B. Mooney, T. Gerngross, J. William, R. Ghanadan, A. Mahone, J. Moore, D. Sharma, B. Saharan, M. Barker, R. Safford. Nevertheless, there is a lack of comprehensive researches concerning advantages and disadvantages of using bioplastics.

The purpose of the article is to investigate the advantages and drawbacks of using bioplastic materials, to explore their environmental, economic and social effects in comparison with the conventional plastics ones.

Research results. According to J. Philp, R. Ritchie and K. Guy, bioplastic usage gives a wide range of benefits for various economic entities. Most of them concern ecological, economic and social aspects of bioplastic ap- plication. Here are the advantages of using bioplastics.

- Decreased carbon footprint. Bioplastics have a special advantage over oil-based plastics to minimize reliance on limited fossil fuels and to shorten the emissions of greenhouse gas by changing the carbon content of plastic products with bio-based content. Most life-cycle studies have found that a reduction of greenhouse gases (GHGs) emissions can be achievable by replacing petroleum-based plastics with bioplastics made from renewable feedstocks, but, noticeably, these analysis have failed to count the carbon emissions that occur as farmers worldwide convert forest and grassland to new cropland to replace the corn diverted to bioplastics [10].

- Lower energy resources consumption (lower reliance on petroleum). Probable oil shortages have caused a significant concern. Development of bioplastics demands lower level of fossil fuel consumption comparing to conventional plastics. For instance, oil-based polymers have been assessed to have the usage level of approximately 68-132 MJ of fossil fuels per $\mathrm{kg}$ of resin produced, comparing to bioplastics below 12MJ per kg [11]. Bioplastics therefore provide a sustainable opportunity to decrease the level of dependency on different non-renewable resources.

- Numerous end-of-life choices. It is possible to use bioplastics for various end-of-life choices. Recycling in a mechanical way has a positive impact on the greenhouse gas balance [6]. Incineration leads to the production of energy, what is advantageous in the context of environmental sustainability. Conventional plastics incineration leads to emissions of fossil $\mathrm{CO}_{2}$, when bioplastics let out natural $\mathrm{CO}_{2}$. Biogas digestion brings in to the production of energy and, consequently, positively affects the balance of greenhouse gases. The significant part of bioplastic products used can be defined as compostable, so diverting litter from dumpsites is possible. It is advantageous to compost biobased plastics is only when it has added value; when it has other advantages such as increasing the quantity of food waste, which is collected for composting, and lowering the amount of conventional plastics that end up in food and garden waste being composted.

- Declining the level of waste pollution and increased compostability of biodegradable bioplastics. Around $14 \%$ of all existing waste 
stream are plastic materials. It is approximately 34 million tons of litter annually, just $11 \%$ of which are directed on recycling [5]. Others go to dumpsites, where the process of decomposing can take more than 100 years. If facilities have the appropriate equipment for composting to manage biodegradable plastics, it is possible to experience a complete breakdown of the material within 18-36 months (it depends on the particular method used) [8]. Even if there is no entire breakdown, it is likely to achieve a shortage in the quantity of space needed to have the products disposed. This would put less strain on the whole garbage stream. Biodegradable items, including food packaging, compostable bio-waste containers or tableware, can be combined with organic waste in special anaerobic digestional or industrial composting plants. Therefore, it is feasible to divert biodegradable plastics from landfills and transform into biogas or compost. It is also possible to use bioplastics to bring out renewable energy, unless they can be recycled or reused [13]. Nevertheless, it is cost-effective to compost biobased plastics if it has added value or if it has other advantages, including expanding the quantity of food waste, which is collected in order to be composted or decreasing the number of oil-based plastic products that end up in food waste that is composted.

- Decreasing the level of greenhouse gas emissions. When using biodegradable plastics instead of conventional processing materials, less greenhouse gas emissions are released into our planet's atmosphere. We consume around 300 million tons of plastics annually (plastic industry releases around one billion tons of $\mathrm{CO}_{2}$, which enter Earth's atmosphere every year [1]. If plastics were fully recycled every year, we would save significant amount of carbon (up to 74\%, according to some researchers). Using bioplastics is able to help to reduce the level of emissions of greenhouse gases generated by different areas of industry in a long-term prospective, in spite of the original financial expenditures for making this switch.

- Work creation. In the expected global net increase in jobs, bioplastics application was revealed to provide a social benefit. It is projected that the employment sector will remain stable in industry, with the growth coming from jobs, which are going to be generated in agriculture. This growth is not sufficient, expected to be around 35,000 new jobs worldwide by 2025 , but remains an opportunity for the bioplastic industry [7].

- Disposal of agricultural film. It has been shown that starch mulch provides an ecological benefit over other alternative options [14]. This is demonstrated mainly by the fact that four times less agricultural film is demanded, but for disposal they also do not need removal from the ground. Undoubtedly, further research is needed, on the effect of degradation of the mulch on the soil.

- Better technical characteristics, including:

- Capability of bioplastics to be clearer and more transparent.

- Better printing performance-simply readable image is more likely to be printed on bioplastic.

- A surface texture of high quality. It is possible to create bioplastics to provide a surface texture that is much more favourable than traditional plastics.

- Bioplastics can be more steam-permeable than a conventional plastic. In some cases, this may be a drawback, such as sandwich packaging, but in the case of freshly baked pie, a bioplastic container will provide a significant advantage in the case of excess steam.

- Better tactility and smoothness, which is a substantial advantage for consumer for such applications as cosmetics packaging.

- Lower probability to give a different taste to the product stored in a plastic container. For instance, dairy products might get a new flavour in plastic dishes, but it is particularly impossible in the bioplastic alternative [4].

However, possible problems might come along with the use of bioplastics. According to G. Davis, J. Song, most obstacles are connected with certain aspects of economic and political life on both micro- and macro levels. Here are the disadvantages of bioplastics application.

- Unsustainable land use. Extra land is needed to make bioplastics in comparison with the oil-based ones. According to reports about development of bioplastic market up to 2030 , only about $0.2-0.5 \%$ of additional land will be required. Though, if land, which is ecologically or socially valuable, is used in unsustainable way, or releases high quantities of stored carbon, this is considered a substantial barrier.

- The price of resin and the amount of sales. It has been found that the bioplastics being studied are more expensive to produce 
and sell than traditional alternatives. For example, polylactic acid (PLA) and cellulose are up to $60 \%$ more expensive than the conventional plastics. Polyhydroxyalcanoates (PHL) and starch cost four times as much as the oilbased plastics [2]. PLA was noticed to provide an economic benefit over polycarbonate when used in long-term applications. This is most likely to be only about $45 \%$ of the material, which is commonly used in such applications. However, it does not account for the comparable price of polymers or additives. It is worth mentioning that the price of bioplastics is expected to decrease as manufacturing efficiencies and scale of retailing rise.

- Current scale of production. Bioplastics account for approximately $0.8 \%$ of the plastics industry now, with the level of production of approximately 2.1 million tons worldwide, much of which is manufactured at low scale [3]. It contrasts with 336 million tons of traditional polymers produced in 2018. This is a significant barrier to the application of bioplastics in the context of volume limits, especially about the economic and environmental barriers in the case of cellulose.

- Low level of consumers' engagement. Due to the inability of the public to classify products as bioplastic ones, the possibilities for segregation are minimal. Therefore, there is a lack of public understanding of the bioplastic products. It is considered to decline willingness of the consumers to pay for bioplastics. According to the 2013 study, conducted by the European Commission, the total majority of consumers in the European Union do not have awareness about positive environmental effects of bioplastics, their advantages (and disadvantages) over conventional plastics.

\section{References}

1. Alvarez-Chavez C. \& Edward R. Sustainability of biobased plastics: general comparative analysis and recommendations for improvement. Journal of Cleaner Production. 2012. № 23(1). P. 47-56.

2. Asrar J. \& Gruys K. J. Biodegradable Polymer. Biopolymers Online. 2015.N 8. P. 47-51.

3. Cherubini $F$. GHG balances of bioenergy systems: overview of key steps in the production chain and methodological concerns, Renewable Energy. 2010. N 35. P. 1565-1573.

4. Green $R$. Bioplastic production from agro-industrial waste. Biotechnology and Bioengineering. 2011. N 108(9). P. 98-104.

5. James K. \& Grant T. Life Cycle Assessment of Degradable Plastic Bags, Journal of Green Economy. 2014. N 17. P. 248-274.

6. Karana E. Characterization of 'natural' and 'highquality' materials to improve perception of bioplastics. Journal of Cleaner Production. 2012. N 37. P. 316-325.
- Legislation problems. With more opportunities provided, bioplastics production is expected to rise to around 8 million tons by 2028 [12]. Nevertheless, many countries in the world (including Ukraine) still do not have any legislative framework for bioplastic use and management of bioplastic waste. A range of legislative acts need to be adopted, including, labeling regulations, possible tax benefits for bioplastics producers and laws to control sustainable land use and provide different end-of-life options.

Conclusions. Using economic, environmental, legislative, technological data, various opportunities and barriers of bioplastics' usage have been determined. Bioplastics seems to have many advantages in comparison with conventional plastics, including decreased carbon footprint, lower consumption of energy, numerous end-of-life choices, reduction of waste, increased compostability of biodegradable bioplastics, decreasing the level of greenhouse gas emissions, work creation, disposal of agricultural film, better technical characteristics. However, the scale of bioplastics production is still low, so its role in green and sustainable economy as a substitute to conventional plastics is still insignificant. It can be explained by certain disadvantages of bioplastics production and application, in particular, such as unsustainable land use, the price of resin and the amount of sales, low level of consumers' engagement, legislation problems. Where barriers in bioplastics' implication have been identified, it is important to continue researching in order to evaluate different aspects of bioplastic market, to anticipate its emerging prospects and to provide recommendations to minimize negative effects of bioplastic usage.

\section{References}

1. Alvarez-Chavez, C. \& Edward, R. (2012). Sustainability of bio-based plastics: general comparative analysis and recommendations for improvement. Journal of Cleaner Production, 23 (1), pp. 47-56 [In English].

2. Asrar, J. \& Gruys, K.J. (2015). Biodegradable polymer. Biopolymers Online, 8, pp. 47-51 [In English].

3. Cherubini, F. (2010). GHG balances of bioenergy systems: overview of key steps in the production chain and methodological concerns. Renewable Energy, 35, pp. 1565-1573 [In English].

4. Green, R. (2011). Bioplastic production from agroindustrial waste. Biotechnology and Bioengineering, 108 (9), pp. 98-104 [In English].

5. James, K. \& Grant, T. (2014). Life cycle assessment of degradable plastic bags. Journal of Green Economy, 17, pp. 248-274 [In English].

6. Karana, E. (2012). Characterization of "natural" and "highquality" materials to improve perception of bioplastics. Journal of Cleaner Production, 37, pp. 316-325 [In English]. 
7. Mahalakshmi V. Evaluation of Biodegradation of Plastics. International Journal of Innovative Research \& Development. 2014. N 3(7). P.185-190.

8. Mekonnen T. \& Mussone P. Progress in bio-based plastics and plasticizing modifications. Journal of Material Chemistry. 2013. N 43(1). P. 179-198.

9. Mooney B. P. The second green revolution? Production of plant-based biodegradable plastics. Biochemical Journal. 2009. N 418(2). P. 219-232.

10. Pasqualino N. The Carbon Footprint and Energy Consumption of Beverage Packaging Selection and Disposal. Journal of Food Engineering. 2011. N 103(4). P. 357-365.

11. Peelman N. \& Ragaert P. Application of bioplastics for food packaging. Trends in Food Science and Technology. 2013. N 32(2). P. 128-141.

12. Piemonte V. \& Gironi F. Land-use change emissions: How green are the bioplastics? Environmental Progress \& Sustainable Energy. 2010. N 30(4). P. 685-691.

13. Sarasa J. \& Gracia J. Study of the biodisintegration of a bioplastic material waste. Bioresource Technology. 2008. № 100(15). P. 376-378.

14. Vaverková M. \& Adamcová D. Biodegrability Of Bioplastic Materials In A Controlled Composting Environment. Journal of Ecological Engineering. 2015. N 16. P. 155-160.
7. Mahalakshmi, V. (2014). Evaluation of biodegradation of plastics. International Journal of Innovative Research \& Development, 3 (7), pp. 185-190 [In English].

8. Mekonnen, T. \& Mussone, P. (2013). Progress in biobased plastics and plasticizing modifications. Journal of Material Chemistry, 43 (1), pp. 179-198 [In English].

9. Mooney, B.P. (2009). The second green revolution? Production of plant-based biodegradable plastics. Biochemical Journal, 418 (2), pp. 219-232 [In English].

10. Pasqualino, N. (2011). The carbon footprint and energy consumption of beverage packaging selection and disposal. Journal of Food Engineering, 103 (4), pp. 357-365 [In English].

11. Peelman, N. \& Ragaert, P. (2013). Application of bioplastics for food packaging. Trends in Food Science and Technology, 32 (2), pp. 128-141 [In English].

12. Piemonte, V. \& Gironi, F. (2010). Land-use change emissions: How green are the bioplastics? Environmental Progress \& Sustainable Energy, 30 (4), pp. 685-691 [In English].

13. Sarasa, J. \& Gracia, J. (2008). Study of the biodisintegration of a bioplastic material waste. Bioresource Technology, 100 (15), pp. 376-378 [In English].

14. Vaverková, M. \& Adamcová, D. (2015). Biodegrability of bioplastic materials in a controlled composting environment. Journal of Ecological Engineering, 16, pp. 155-160 [In English].

Мельник Л.Г., Кубатко О.В., Півень В.С., Кучеренко П.В., Іанатченко В.М. Виробництво біопластику для циркуляційної економіки і стимулювання сестейнового розвитку

Мета статmi - дослідити переваги і недоліки використання біопластику в системі господарювання, його екологічні, економічні й соціальні ефекти порівняно зі звичайними пластмасами.

Методика дослідження. Використано метод порівняльного аналізу для розгляду переваг і недоліків використання біопластику.

Результати дослідження. Визначено, що біопластик має особливі екологічні переваги порівняно із звичайними пластиками, зокрема, мінімізується залежність від вичерпного викопного палива та зменшуються викиди парникових газів. Крім того, відзначається, що біопластик сприяє посиленню енергетичної безпеки вітчизняної економіки за рахунок зниження споживання енергоресурсів і меншої залежності від нафти. Короткострокові економічні переваги біопластику не забезпечують переваг над звичайними пластиками. Однак довгострокова перспектива виробництва біопластику явно виражена завдяки зниженню рівня забруднення та підвищенню сумісності з природними компонентами, насамперед із грунтом. Згідно з одержаними результатами, біопластики мають багато переваг порівняно зі звичайними пластмасами, включаючи зменшення кількості вуглецевих відходів, зниження споживання енергії, наявність численних варіантів закінчення терміну експлуатації, зменшення відходів, підвищення сумісності пластиків, що біоразкладаються, зниження рівня викидів парникових газів, створення робочих місць, утилізація сільськогосподарських (споживчих) упаковок, кращі технічні характеристики. Ці переваги сприяють зростанню ринку біопластику. Однак нестабільне використання землі, цінові нафтові шоки, низький рівень залучення споживачів, проблеми законодавства розглядаються як суттєві бар'єри для збільшення використання біопластику.

Елементи наукової новизни. Запропоновано теоретичну концепцію виробництва біопластику, яка на відміну від існуючої враховує його переваги і недоліки на всіх етапах життєвого циклу продукції для стимулювання циркуляційної економіки та сприяння сталому розвитку.

Практична значущість. Полягає у можливості використання запропонованих підходів як для розробки бізнес-планів реальних проектів, так і стратегій місцевого розвитку. Бібліогр.: 14.

Ключові слова: біопластик; переваги біопластику; недоліки біопластику; сестейнова економіка; зелена економіка.

Мельник Леонід Григорович - доктор економічних наук, професор, завідувач кафедри економіки, підприємництва і бізнес-адміністрування, Сумський державний університет, директор Науково-дослідного інституту економіки розвитку МОН України і НАН України у складі Сумського державного університету (м. Суми, вул. РимськогоКорсакова, 2)

E-mail: melnyk@econ.fem.sumdu.edu.ua

ORCID iD https://orcid.org/0000-0001-7824-0678

Кубатко Олександр Васильович - доктор економічних наук, професор, доцент кафедри економіки, підприємництва і бізнес-адміністрування, Сумський державний університет (м. Суми, вул. Римського-Корсакова, 2)

E-mail: okubatko@ukr.net

Півень Владислав Сергійович - студент Навчально-наукового інституту фінансів, економіки і менеджменту імені Олега Балацького, Сумський державний університет (м. Суми, вул. Римського-Корсакова, 2)

E-mail: a.piven@ms.sumdu.edu.ua

Кучеренко Поліна Валеріївна - студент Навчально-наукового інституту фінансів, економіки і менеджменту імені Олега Балацького, Сумський державний університет (м. Суми, вул. Римського-Корсакова, 2)

E-mail: Poulina.Kucherenko@gmail.com

Ігнатченко Віталій Михайлович - аспірант кафедри економіки, підприємництва і бізнес-адміністрування, Сумський державний університет (м. Суми, вул. Римського-Корсакова, 2)

E-mail: Ignatchenko91@e-mail.ua 
Мельник Л.Г., Кубатко А.В., Пивень В.С., Кучеренко П.В., Игнатченко В.М. Производство биопластика для циркуляционной экономики и стимулирования сестейнового развития

Цель статьи - исследовать преимущества и недостатки использования биопластика в системе хозяйствования, его экологические, экономические и социальные эффекты по сравнению с обычными пластмассами.

Методика исследования. Использован метод сравнительного анализа для рассмотрения преимуществ и недостатков использования биопластика.

Результаты исследования. Определено, что биопластик имеет особые экологические преимущества по сравнению с обычными пластиками, в частности, минимизируется зависимость от исчерпаемого ископаемого топлива и уменьшаются выбросы парниковых газов. Кроме того, отмечается, что биопластик способствует усилению энергетической безопасности отечественной экономики за счет снижения потребления энергоресурсов и меньшей зависимости от нефти. Краткосрочные экономические преимущества биопластика не обеспечивают преимуществ по сравнению с обычными пластиками. Однако долгосрочная перспектива производства биопластика явно выражена благодаря снижению уровня загрязнения и повышению совместимости с природными компонентами, прежде всего с почвой. Согласно полученным результатам, биопластики имеют много преимуществ по сравнению с обычными пластмассами, включая уменьшение количества углеродных отходов, снижение потребления энергии, наличие многочисленных вариантов окончания срока эксплуатации, уменьшение отходов, повышение совместимости биоразлагаемых пластиков, снижение уровня выбросов парниковых газов, создание рабочих мест, утилизация сельскохозяйственных (потребительских) упаковок, лучшие технические характеристики. Эти преимущества способствуют росту рынка биопластика. Однако нестабильное использование земли, ценовые нефтяные шоки, низкий уровень привлечения потребителей, проблемы законодательства рассматриваются как существенные барьеры для увеличения использования биопластика.

Элементы научной новизны. Предложена теоретическая концепция производства биопластика, которая в отличие от существующей учитывает его преимущества и недостатки на всех этапах жизненного цикла продукции для стимулирования циркуляционной экономики и содействия устойчивому развитию.

Практическая значимость. Состоит в возможности использования предложенных подходов как для разработки бизнес-планов реальных проектов, так и стратегий местного развития. Библиогр.: 14.

Ключевые слова: биопластик; преимущества биопластика; недостатки биопластика; сестейновая экономика; зеленая экономика.

Мельник Леонид Григорьевич - доктор экономических наук, профессор, заведующий кафедрой экономики, предпринимательства и бизнес-администрирования, Сумской государственный университет, директор Научноисследовательского института экономики развития МОН Украины и НАН Украины в составе Сумского государственного университета (г. Сумы, ул. Римского-Корсакова, 2)

E-mail: melnyk@econ.fem.sumdu.edu.ua

ORCID iD https://orcid.org/0000-0001-7824-0678

Кубатко Александр Васильевич - доктор экономических наук, профессор, доцент кафедры экономики, предпринимательства и бизнес-администрирования, Сумской государственный университет (г. Сумы, ул. РимскогоКорсакова, 2)

E-mail: okubatko@ukr.net

Пивень Владислав Сергеевич - студент Учебно-научного института финансов, экономики и менеджмента имени Олега Балацкого, Сумской государственный университет (г. Сумы, ул. Римского-Корсакова, 2)

E-mail: a.piven@ms.sumdu.edu.ua

Кучеренко Полина Валериевна - студентка Учебно-научного института финансов, экономики и менеджмента имени Олега Балацкого, Сумской государственный университет (г. Сумы, ул. Римского-Корсакова, 2)

E-mail: Poulina.Kucherenko@gmail.com

Игнатченко Виталий Михайлович - аспирант кафедры экономики, предпринимательства и бизнесадминистрирования, Сумской государственный университет (г. Сумы, ул. Римского-Корсакова, 2)

E-mail: Ignatchenko91@e-mail.ua

The article has been received 02.11.2019

Revision: 12.11.2019

Бібліографічний опис для цитування:

Melnyk L.H., Kubatko O.V., Piven V.S., Kucherenko P.V., Ihnatchenko V.M. Bioplastics production for circular economy and sustainable development promotion. Економіка АПК. 2019. № 11. С. 79 - 84. 